\title{
Ruminations About Ideology, Law, and Labor Arbitration
}

\author{
Bernard D. Meltzer
}

I propose to say something about three persistent and interdependent questions: First, is the arbitration system especially vulnerable to pressures that are incompatible with a fair and even-handed disputesettling mechanism? Second, what is the appropriate role of the courts in actions challenging an award as wholly incompatible with the governing agreement? Third, what is the proper role of the arbitrator with respect to statutory or policy issues that are enmeshed with issues concerning the interpretation of the collective bargaining agreement?

The first two issues have been highlighted by the sharply conflicting assessments of arbitration by Mr. Justice Douglas and Judge Hays. There are several ironic aspects to their disagreement. Mr. Justice Douglas, evidencing an unusual devotion to the passive virtues, said in effect: "Anything We Can Do, Arbitrators Can Do Better." Judge Hays, although an eminent ex-arbitrator, implied: "They Got Plenty O' Nuttin" " and "Let's Call the Whole Thing Off." Incidentally, my own view ${ }^{1}$ about each of those performances is: "It Ain't Necessarily So."

Before venturing some comments about the principal counts in Judge Hays' indictment, let me summarize my views about his methodology. His charges generally suffer from a painful lack of documentation, and when he reaches for evidence, his methods are distorted by a passion for denunciation. In short, he has substituted for the Supreme Court's mythology of arbitral excellence a new mythology of arbitral corruption and incompetence.

Any judgment about the competence of arbitrators is complicated by two factors. First, arbitration is obviously not a unitary system. It

Bernard D. Melzer, Professor of Law, the University of Chicago, received an A.B. degree in 1935 and a J.D. degree in 1938 from the University of Chicago. This paper was delivered at the annual meeting of the National Academy of Arbitrators on March 2, 1967.

1 See Meltzer, The Supreme Court, Arbitrability, and Collective Bargaining, 28 U. CHr. L. Rev. 464 (1960); Meltzer, Book Review, 34 U. CHr. L. REv. 211 (1966). That review is the source of the comments below about the general fitness of arbitration as a method of adjudication. 
reflects all the diversities that apply to any single professional group and compounds those diversities by drawing its personnel from a smorgasbord of occupations, all of which may, or may not, constitute a profession. Second, a good deal of arbitration is invisible because only a small proportion of awards are published and because an award is, of course, only a fragment of the total proceeding. For these reasons, I will not engage in the act of faith or despair that any blanket indictment or eulogy involves. But, in accordance with a suggestion by Professor Edgar Jones that arbitrators should keep their humility in order, I want to quote a short passage from Bernard Dunau's critical review of Hays' lectures. "It is unfortunately true," Dunau said, "that the level of judging, whether judicial, administrative or arbitral, is in the overall quite mediocre, but for those who have worked in all three forums, the arbitrator does not suffer by comparison."2 In any case, the parties can much more easily escape from mediocrity in arbitration than in other forums, although their freedom to do so is, of course, limited by the need for joint acceptability.

It is that need which is the basis for the principal count in Hays' indictment. "A proportion of arbitration awards," he tells us, " . . . are decided not on the basis of the evidence or of the contract or other proper considerations" but in a way designed to preserve the arbitrator's employability. ${ }^{3}$ And he goes on to suggest that, regardless of the proportion of such awards, which is unknown, a system of adjudication in which the judge's income depends on pleasing those who engage him is per se a thoroughly undesirable system, wholly incompatible with the independence a judicial officer should have. ${ }^{4}$ This charge plainly goes to the heart of the system and is wholly independent of varying estimates of arbitral competence, although it may have some relationship to occasional excrescences of the system, such as the rigged award.

There is, in my opinion, some basis for the fear that economic selfinterest and the desire to be loved, which are linked with future acceptability, will distort adjudication. Such a risk must be acknowledged unless all arbitrators are angels-a position that even $\mathrm{Mr}$. Justice Douglas or, indeed, arbitrators themselves are unlikely to accept. But Judge Hays ignores two important considerations. First, all systems of adjudication involve a similar risk. Second, important safeguards against self-regarding adjudication are built into the arbitration system. The neglect of those safeguards has, in my opinion, led Judge Hays greatly to overrate the distortion that actually results from the need for acceptability.

2 Dunau, Book Review, 1966 The Amerucan Scholar 774-76.

3 Hays, Labor ARbitration: A Dissenting View 112 (1966).

4 Ibid. 
Those safeguards are well-known and have been effectively presented in Saul Wallen's review ${ }^{5}$ of Hays' book. Nevertheless, they bear restatement because of their fundamental importance to the integrity of the arbitration system. The losing party is generally the principal threat to the arbitrator's future acceptability. To be sure, even winners grumble about an arbitrator's handling of the hearing or the quality of his opinion, but such complaints are healthy because they suggest that acceptability turns on the overall quality of the arbitrator's performance and not merely on his decision. In any event, the principal question for an arbitrator, assuming for the moment that he is ruled by a greedy desire for more customers, is how to reduce the risk implicit in the fact that one party generally will lose. I can think of no better answer to that question than conscientious workmanship, for such workmanship appears to be the best protection against the veto that labor and management will each be able to exercise in the future. The need for future acceptability would thus appear to bring the arbitrator's self-interest and disinterested adjudication into harmony rather than conflict. Consequently, even if one accepted a devil's view of arbitrators as a group ruled by love of money, it would not follow that the pressure for future acceptability would corrupt the decisional process. On the contrary, the "invisible hand," so dear to some of my economist friends, appears in the context of arbitration to link the private ends of arbitrators with the public interest in justice. That kind of harmony between private and public purposes is important for the suitability of any adjudicative arrangement and becomes of critical importance as the number of arbitrators devoting substantially full time to arbitration increases.

The devil's theory of arbitration rests, moreover, on some dubious presuppositions about arbitrators as a class. It presupposes that they lack a sense of integrity, of craftsmanship, and of self-respect, and that they are essentially a craven group of money-grubbers, abjectly fearful of displeasing their customers and willing to default on their responsibilities to avoid such displeasure. I find no basis in Hays' book or in my experience for so denigrating a view. Indeed, the arbitrators whom I know impress me as conscientious men, who are willing to call them as they see them. Differing judgments about the character of a large and shifting class may result, of course, from different slices of experience and different standards of judgment, and I do not claim an adequate basis for reliable generalizations about a heterogeneous and largely invisible group.

Judge Hays' view of the parties is no more flattering than his view of

5 Arbitrators and Judges-Dispelling the Hays' Haze, S.W. LEGAL Foundation 12TH INSTITUTE ON LABOR LAW 159 (1966). 
arbitrators. He sees the parties with their weapons of economic reprisal ready for use against the arbitrator who rules against them. That view ignores that the parties are sometimes shaken and occasionally even persuaded by a well-reasoned opinion and that the parties also understand that honest and reasonable men may disagree. There are, moreover, bits and pieces of evidence that call into question the judge's dismal forebodings. There are, to my knowledge, refreshing instances where the loser has praised the arbitrator's opinion and has called on him for more work. There are also denials by lawyers appearing in arbitrations that they respond to defeat with indignation or blacklisting. Finally, it is striking that lawyers for unions and management are respected arbitrators. Their reputation for integrity and competence has overcome suspicions of partisanship generated by their associations or their view of the world. It is, of course, possible that one canny forum-shopper will rely on the partisan connections of an arbitrator to influence him to lean over backwards, while the other side will rely on his doing what comes naturally. But, if my thoroughly unscientific poll of lawyers is reliable, it is not such gamesmanship that is at work, but rather the parties' confidence that men of integrity and competence can, as adjudicators, transcend their personal loyalties and discipline their personal values. It is the existence of such a tradition in arbitration, as in law or medicine, that is, in my view, the decisive condition for an acceptable system, and I am confident that that condition is usually satisfied.

Furthermore, Judge Hays, as I have already suggested, fails to consider the extent to which similar pressures operate on official tribunals. I do not mean to justify distortion, partisanship, or sloppiness in arbitration by pointing to their existence elsewhere. But the Judge was engaged in comparing alternative tribunals in a real world. Accordingly, the methods of staffing official tribunals, such as the labor court proposed by Hays, deserve attention. This is not the place for an extended discussion of the factors that enter into the selection of administrative and

. judicial personnel. It is enough to say that the politics of patronage often entrust adjudication to mediocrities, who may seek to remain acceptable to those who have conferred past favors and who may determine future preferment. Indeed, as has been suggested from time to time, ${ }^{6}$ the fear of partisan and mediocre official tribunals has contributed to the growth of labor arbitration. The existence of such fears underscores the limitations in an appraisal of arbitration that, like Judge Hays', exaggerates the vices of arbitrators, then assumes that

6 See, e.g., Aaron, On First Looking into the Lincoln Mills Decision, National AcadeMY of Arbitrators, 12th Annual Meeting Proceedings 12 (1959). 
alternative machinery would conform to an ideal model, and finally concludes that arbitration should be supplanted by new tribunals or that there should be a fundamental alteration in the relationship between arbitration and the judicial system.

Even if Judge Hays' dismal appraisal had the analytical and empirical support that it conspicuously lacks, some might suggest that the parties shape and pay for their dispute-settling mechanism and that their choice of a fool or a rogue for an umpire is private rather than public business. That suggestion would, in my view, be manifestly erroneous because it would brush aside important public dimensions of this private system.

Arbitration is an adjunct of a bargaining system that has been shaped by the compulsion of law. Furthermore, both the courts and national and state legislatures have endorsed arbitration; indeed, the courts had placed their coercive power behind arbitration awards long before Lincoln Mills $^{7}$ and the Steelworkers Trilogy ${ }^{8}$ made arbitration the darling of national labor policy.

The public interest is also involved because arbitration constitutes an alternative and an obstacle to the use of official machinery. Thus, prior resort to arbitration, and indeed its pendency or availability, may move the NLRB to withhold its jurisdiction and may also influence the substance of the Board's action where it takes jurisdiction. ${ }^{9}$ Similarly, under the Norris-LaGuardia Act, a moving party may be denied injunctive relief against serious acts of violence on the ground that he has rejected arbitration..$^{10}$ Finally, it has been held ${ }^{11}$-erroneously I believe, although I will not argue the point-that arbitral determinations are, in some circumstances, binding in connection with related causes of action maintained in the courts. Plainly, such displacement of official machinery by arbitration would be intolerable if arbitration, as Judge Hays charged, were per se a thoroughly undesirable method of adjudication.

The final dimension of the public interest in arbitration is the most important and the most obvious one. Arbitration is designed primarily as an instrument of justice for the industrial community, and the state could not properly rely on an inadequate market mechanism to dis-

7 Textile Workers v. Lincoln Mills, 353 U.S. 448 (1957).

8 United Steelworkers v. American Mfg. Co., 363 U.S. 564 (1960); United Steelworkers v. Warrior \& Gulf Nav. Co., 363 U.S. 574 (1960); United Steelworkers v. Enterprise Wheel \& Car Corp., 363 U.S. 593 (1960).

- See, e.g., International Ass'n of Machinists (J.A. Jones Construction Co.), 135 N.L.R.B. 1402, 49 L.R.R.M. 1684 (1962).

10 Trainmen v. Toledo P. \& W.R.R., 321 U.S. 50 (1943). But cf. Local 721 v. Needham Packing Co., 376 U.S. 247 (1964).

11 Los Angeles Paper Bag Co. v. Printing Specialties Union, 345 F.2d 757 (9th Cir. 1965). 
charge one of its fundamental responsibilities. Furthermore, the quality of arbitral performance will not only affect equity and efficiency in the plant but will also have consequences that radiate far beyond the plant. To workers, the line between official and private adjudication is likely to be an unimportant one; and the integrity, actual and apparent, with which arbitrators discharge their function will influence the respect of employees, among others, for the rule of law generally. That consideration, however imponderable, takes on a special importance when the idea of law is being challenged by recourse to force in many sensitive areas of our national life.

The achievement of the private and public purposes linked to arbitration depends on a suitable coordination of the judicial and the arbitral functions, and it is one aspect of that problem which I now want to explore. The Supreme Court, seeking such coordination in the Steelworkers Trilogy,12 emphasized that in general the "merits" were for arbitrators rather than the courts. Those cases, and Enterprise Wheel ${ }^{13}$ in particular, were, however, not crystal clear as to whether the severe limitations imposed on courts when the issue was whether a dispute should be arbitrated were to be equally applicable when the issue was whether an award should be enforced.

In Enterprise Wheel, the Court declared:

An arbitrator is confined to interpretation and application of the collective bargaining agreement; he does not sit to dispense his own brand of industrial justice. . . . He may, of course, look for guidance from many sources, yet his award is legitimate only so long as it draws its essence from the collective bargaining agreement. When the arbitrator's words manifest an infidelity to his obligation, courts have no choice but to refuse enforcement of the award. ${ }^{14}$

That passage is susceptible to conflicting interpretations as to the scope of post-arbitral review. Under one interpretation, the arbitrator's award or his remedy is not to be disturbed, provided that he says that his award rests on the agreement. It is only when his "words," as distinguished from his result, manifest an infidelity to the agreement that judicial enforcement of his award is to be denied. In other words, unless the arbitrator confesses that he has strayed beyond the agreement,

12 United Steelworkers v. American Mfg. Co., 363 U.S. 564 (1960); United Steelworkers v. Warrior \& Gulf Nav. Co., 363 U.S. 574 (1960); United Steelworkers v. Enterprise Wheel \& Car Corp., 363 U.S. 593 (1960).

13 United Steelworkers v. Enterprise Wheel \& Car Corp., 363 U.S. 593 (1960).

14363 U.S. at 597 (emphasis added). 
his award is to be treated as drawing its essence from the agreement. ${ }^{15}$ That interpretation would serve to exclude courts from the merits and would, accordingly, be faithful to the basic thrust of the Trilogy.

Nevertheless, that interpretation is not without its difficulties. It would provide for a somewhat sterile regulation of the arbitrator's rhetoric but not his action. It would, accordingly, not reach situations where his action, speaking louder than his words, plainly appeared not to draw its essence from the collective bargaining agreement. Furthermore, that interpretation might result in discouraging arbitrators from writing opinions, which the Court said were a good idea.

In his lectures, Judge Hays rejected judicial review limited to the rhetoric of the award, and as to post-award review supported a distinction made by the Second Circuit between an arbitrator's "jurisdiction" to be wrong and his "authority" to decide issues contrary to the contract. ${ }^{16}$ Perhaps others will find that distinction clearer than I do. My puzzlement results from my assumptions that the arbitrator is wrong only when he decides issues contrary to the contract and that, accordingly, if he has jurisdiction to be wrong, he has jurisdiction to decide things in a way that a court would consider contrary to the contract. Perhaps, the distinction is between an arbitrator's jurisdiction to be "wrong" and his jurisdiction to be "preposterously wrong."

Despite my doubts about the meaning of the Second Circuit's distinction, I am certain that that distinction foreshadows another confrontation between courts and arbitrators as to who is to be master of the merits in actions to enforce or vacate the award. Consider, for example, the familiar clause barring the arbitrator from adding to or subtracting from or altering the provisions of the agreement. In almost every case, the disappointed party will be able to point to that clause as a restriction on the arbitrator's award-granting authority. Furthermore, a judicial determination as to whether the arbitrator observed that restriction would almost always involve a scrutiny of the merits. Finally, even where such a restriction has not been expressly incorporated into the agreement, one could be fairly implied, on the basis, indeed, of the Court's statement in Enterprise Wheel limiting the arbitrator to the interpretation and administration of the agreement.

The difficulties I have just mentioned were sharpened by Torrington Co. v. Metal Products Workers, ${ }^{17}$ recently decided by a divided Second Circuit. That case involved a twenty-year policy that granted employees

15 See Meltzer, The Supreme Court, Arbitrability, and Collective Bargaining, $28 \mathrm{U}$. CHr. L. REv. 464, 484-85 (1960).

16 Hays, supra note 3 , at $80-82$

17 362 F.2d 677 (2d Cir. 1966). 
paid time-off for voting. That policy had been unilaterally established by the company, had never been incorporated in an agreement, and had been formally and publicly renounced by the company about ten months before the expiration of a prior agreement. In negotiations for the renewal of the agreement that governed the grievance, the company had stated that it would not re-establish the former policy, whereas the union had called for its re-establishment. The agreement, executed after a long strike in the course of which non-strikers had not been given paid time-off for voting, was silent about that matter. A grievance led to an award that the company remained bound by the established practice until it was changed by mutual agreement. The trial court's decision vacating that award was affirmed by the Second Circuit on the following grounds: (1) The arbitrator had ignored the company's revocation of its past policy; that revocation had been excluded from arbitration by the narrow arbitration clause incorporated in the prior agreement and had, accordingly, been a matter for the company's discretion. ${ }^{18}$ (2) The arbitrator, who had been barred by the governing agreement from adding to its terms, had ignored the fact that "labor contracts generally state affirmatively what conditions the parties agree to, more specifically, what restraints the parties will place on management's freedom of action"19 and had, consequently, erred in placing on the company the burden of securing the union's consent to the abandonment of the pre-existing policy. ${ }^{20}$

Judge Hays did not sit in Torrington, but his ideas were there. His colleagues' opinion quoted this statement from his lectures: "No great harm is done by applying a liberal rule as to arbitrability if the court carefully scrutinizes what the arbitrator later decides."21 The court

18 See note 20 infra for a comparison of the two arbitration clauses.

19362 F.2d 677, 681 (2d Cir. 1966).

20 The prior agreement had provided: "The arbitrator is bound by and must comply with all the terms of this agreement, and he shall not have any power whatsoever to arbitrate away any part of the agreement, nor add to, delete from, or modify, in any way, any of the provisions of this agreement. The company's decisions will stand and will not. be overruled by an arbitrator unless the arbitrator can find that the company misinterpreted or violated the express terms of this agreement." Id. at $681 \mathrm{n} .7$ (emphasis added).

The later agreement, under which the disputed award had been rendered, retained the first sentence quoted above, except for formal changes, omitted the sentence italicized above, and added provisions denying arbitral power over merit increases or wage determinations. $I d$. at 678 n.2.

The court summarily dismissed the possibility that the change in the arbitration provisions, which had been one of the causes of a 16-week strike, implied a rejection of the "reserved rights" theory. Id. at $681 \mathrm{n}$.7. The court, however, surprisingly failed to mention that the later agreement contained an integration clause-a point that had been emphasized in the company's brief. See 41 N.Y.U.L. REv. 1220, 1224 n.29 (1966).

21362 F.2d at 679-80 n.4. 
then delineated the respective roles of the arbitrator and the reviewing court as follows: First, an arbitrator must stay within the confines of the agreement. Second, a reviewing court has a correlative responsibility to enforce that limitation; e.g., to pass on whether the agreement authorizes the arbitrator to expand its express terms on the basis of past practice. Third, the court should not accept the arbitrator's decision where the court can clearly perceive that the arbitrator has derived his authority from sources outside the agreement. The court recognized that its approach might be objected to as an impermissible judicial intrusion on the merits. ${ }^{22}$ But the court, relying on the passage from $E n$ terprise Wheel quoted above, dismissed that objection.

The dissenter in Torrington, who also invoked the language of $E n$ terprise, found that objection decisive and forcefully urged that the majority, by examining the merits of the award, had disregarded the mandate of the Trilogy. ${ }^{23} \mathrm{He}$ urged also that the majority had in effect revived the Cutler-Hammer ${ }^{24}$ doctrine for post-award proceedings by substituting a new catch-phrase_-"the arbitrator's authority"-for "the arbitrator's jurisdiction."25

The dissent is, in my view, more faithful to the central thesis of the Trilogy. Nevertheless, I would renew an earlier suggestion-that the courts in actions involving the validity of the award should have more responsibility for the merits than in actions to compel arbitration. ${ }^{26}$ Unlike the Second Gircuit's and Judge Hays' view, that suggestion does not rely on what is, I believe, an unworkable and spurious dichotomy between "jurisdiction" and "authority," but on the following considerations: At the enforcement stage, the court would have the benefit of the arbitrator's expertise in the same way as a court reviewing the decisions of an administrative agency has the benefit of administrative expertise. The suggested approach would, moreover, permit the arbitration process to realize its potential for therapy and would, at the same time, recognize that the award, although therapy for one party, may be poison to the agreement, whose purpose, after all, is to provide a code for both parties rather than a couch for one of them. Beyond those considerations are more important ones that go to the responsible exercise of judicial power. It is, I believe, questionable to require courts to rubber-stamp the awards of private decision-makers when the courts

22 Id. at $680-81$ n.6.

23 Id. at 682-83.

24 International Ass'n of Machinists v. Cutler-Hammer, Inc., 297 N.Y. 519, 74 N.E.2d 464 (1947).

25 See 362 F.2d at 684 .

26 See Meltzer, supra note 15 , at 485. 
are convinced that there is no rational basis in the agreements for the awards they are asked to enforce. In no other area of adjudication are the courts asked to exercise their powers while they are denied any responsibility for scrutinizing the results they are to enforce. The courts, moreover, exercise such responsibility in areas at least as complex and specialized as labor arbitration, whose mysteries have, I believe, been sometimes exaggerated. In any case, the unique attempt to shrivel judicial responsibility in enforcing arbitration awards is likely to fail because it runs against the grain of judicial tradition. It is thus not surprising that other circuits have adopted an approach similar to that of the Second Circuit.27

The exercise of some judicial responsibility for the results to be enforced seems to me not only inevitable but desirable from the standpoint of arbitration. I do not, of course, mean to suggest the desirability of frequent recalcitrance by the losing party and frequent appeals to the courts. Arbitration is already sufficiently expensive and slow. But the prospect of responsible, albeit limited, judicial review, even though rarely resorted to, is likely to deepen the arbitrator's sensitivity to the admonition in Enterprise Wheel about the sources of his authority. The existence of a judicial check on arbitral aberrations is, moreover, likely to make the parties, and especially employers, more willing to agree to arbitration clauses, without demands for exclusion clauses that multiply issues in negotiations. Finally, such review would presumably promote clearer and better reasoned opinions by arbitrators. In short, I am suggesting that limited judicial review in this context would have its customary institutional values. ${ }^{28}$

There are serious risks, as well as substantial values, involved in even such drastically limited judicial review. The overriding risk is, of course, unenlightened, heavy-handed, and excessive intervention. But that risk is much smaller than it was a generation ago, because of the work of the National Academy of Arbitrators, because of the emphasis the Supreme Court has given to the values of arbitral autonomy, and because the parties generally realize that such values are jeopardized by excessive reliance on the courts. Indeed, in the Midwest long before

27 See, e.g., H. K. Porter v. United Saw File Prod. Workers, 333 F.2d 596 (3d Cir. 1964), involving pro rata pensions for employees who had not fulfilled service requirements and who were terminated as a result of substantial relocation of facilities, discussed in Hays, supra note 3 , at 100-02. For a discussion of bases for granting pro rata pensions in such circumstances, see Bernstein, Future of Private Pensions, ch. 4 (1964).

See also Truck Drivers Union v. Ulry-Talbert Co., 330 F.2d 562, 565 (8th Cir. 1964); cf. Textile Workers v. American Thread Co., 291 F.2d 894 (4th Cir. 1961).

28 Cf. St. Joseph Stock Yards Co. v. United States, 298 U.S. 38, 79 (1936) (Brandeis, J., concurring). 
the Trilogy the parties rarely challenged an award. Thus, when the enactment of the Uniform Arbitration Act was being considered in Illinois, knowledgeable persons could not point to a single instance of recalcitrance. I will resist the temptation to speculate about why there has been considerably greater resort to the courts in the East.

The risks of judicial review might, moreover, be moderated by a limiting formula, even though a tradition of judicial self-limitation is more important than limiting verbalisms. Nevertheless, such a tradition might be developed or strengthened by analogizing to the limitation on judicial review of a master's findings in the federal courts. Such findings are to be respected unless manifestly erroneous and thus are entitled to even more deference than those of administrative agencies. In the context of arbitration, such a formula would mean that the award would be enforced unless it clearly lacked a rational basis in the agreement read in the light of the common law of the plant where appropriate.

In this connection, the report of the Senate Subcommittee on Labor concerning the 1966 amendments to the judicial review provisions of the Railway Labor Act is instructive. That report, after referring to the rejection of a proposal that "arbitrariness" or "capriciousness" be grounds for setting aside an award, stated: "This was done on the assumption that a Federal Court would have the power to decline to enforce an award which was actually and undisputedly without foundation in reason or in fact, and the committee intends that, under this bill, the courts will have that power." 29 The proposal I have advanced for arbitration subject to Section 301 is in substance similar to the assumption behind the RLA amendment-an amendment that sought to subject the two arbitration systems to the same kind of judicial review.

There is another less important risk involved in even limited judicial review: it might compel arbitrators to write opinions in all cases with a view to insulating their awards against judicial reversals. Indeed, Professor Wellington, who has also suggested that courts should exercise more responsibility when their enforcement powers are invoked, has intimated that arbitrators might or should be required to write opinions. ${ }^{30}$ Although I concede that a well-reasoned opinion is generally desirable, I doubt that courts would or should impose an inflexible requirement as to opinion-writing. In most cases, the award itself will clearly draw its essence from the agreement. Even

29 See S. ReP. No. 1201, 89th Cong., 2d Sess. 3 (1966).

30 See Wellington, Judicial Review of the Promise to Arbitrate, 37 N.Y.U.L. REv. 471, 483 (1962). 
in the cases where that relationship is not self-evident, an opinion, although especially useful, need not be required since the brief of the party that prevails in arbitration can present the basis for the award. Perhaps, however, a requirement, like that imposed on trial courts, to set forth findings of fact would be desirable. Such a requirement would merely recognize the obligation that every conscientious arbitrator imposes on himself. ${ }^{31}$

I realize that a proposal for a recognition of increased judicial responsibility in the post-award proceedings will strike many as a heretical retrogression that involves substantial threat to the arbitration process. I concede that danger, and that there is plenty of room for reasonable disagreement about the desirability of increased judicial review, the possibility of limiting it, and indeed whether the formula I am suggesting would increase judicial review or would, as I believe, only bring it out into the open. In any event, let me make it clear that my position does not rest on the ideology of despair but rather on the conviction that arbitration, like other systems of adjudication, should not be able to conscript judicial power while denying judicial responsibility; that the courts would exercise their limited responsibility judiciously; and that such limited judicial supervision would strengthen the institution of arbitration.

Arbitral fidelity to the agreement is also involved in the last question I shall discuss: the arbitrator's responsibility when an award warranted by the agreement would be repugnant to an applicable federal or state policy or rule of public policy.

The following situations suggested by recent cases illustrate the general questions involved: First, a grievant who volunteered to attend a training course paid for by the employer claims overtime for travel to and from school. Under the governing contract read in the light of past practice, it is clear that the grievant's claim would be denied, but the arbitrator reads the Fair Labor Standards Act as requiring payment for travel time. ${ }^{32}$ Second, a layoff is plainly consistent with the agreement but is attacked as involving discrimination repugnant to Title VII of the Civil Rights Act. ${ }^{33}$ A similar issue may be raised when there

31 A transcript of the proceedings would not be a prerequisite for judicial review of an award. Cf. Griffin v. Illinois, 351 U.S. 12, 20, 24, 30-31 (1956).

32 Pennsylvania Electric Co., 47 Lab. Arb. 526 (1966) (E. Stein, Arbitrator).

33Eaton Mfg. Co., 47 Lab. Arb. 1045-50 (1966) (Kates, Arbitrator) (arbitration clause restricting arbitration to grievances "involving interpretation of the contract" does not confer jurisdiction over grievance that employer, although observing the provisions of the agreement concerning bumping and recall of females from layoff violated Title VII of the Givil Rights Act of 1964); cf. UAW v. Chace, 262 F. Supp. 114, 64 L.R.R.M. 2098 (E.D. Mich. 1966); Southern Airways, Inc., 47 Lab. Arb. 1135, 1140 (1966). 
is no contractual basis for requiring an employer to supply information that would be required by the NLRB as an incident of the duty to bargain in good faith. ${ }^{34}$ Since that issue is to get major attention later on in these proceedings, I will do no more than mention it here.

In the first two situations I have described, what effect, if any, should the arbitrator give to the law, which, we will assume, would be contravened by an award based on the agreement?

Before exploring that question, it is appropriate to distinguish it from other questions that have a surface similarity but are fundamentally different. One such question is how the just-cause standard should be applied and the applicable burden of persuasion defined where a grievant's employment, as in the case of an airline pilot, involves substantial risks to the public and to fellow-employees and where regulation imposes duties on employers that reflect the risks involved. In such situations, there is no necessary incompatibility between the contractual standard and that drawn from regulation or public policy;35 for the contractual standard is formulated loosely, presumably for the purpose of permitting consideration of all relevant factors, including, of course, the relevant regulation or public policy. Similarly, where a contractual provision is susceptible to two interpretations, one compatible with and the other repugnant to an applicable statute, the statute is a relevant factor for interpretation. Arbitral interpretation of agreements, like judicial interpretation of statutes, should seek to avoid a construction that would be invalid under a higher law. In both of the situations just mentioned, the arts of construction and the actual or imputed intention of the parties make it possible to avoid a direct conflict between the agreement and the law.

Where, however, there is an irrepressible conflict, the arbitrator, in my opinion, should respect the agreement and ignore the law. My position is based on several interrelated considerations. The first one is the mandate implicit in the following statement from Enterprise Wheel: "It [the award] may be read as based solely upon the arbitrator's view of the requirements of enacted legislation, which would mean that he exceeded the scope of his submission." 36 The basis for that approach is,

For a questionable assertion of sweeping powers by an arbitrator, see Hotel Employers Ass'n of San Francisco, 47 Lab. Arb. 873 (1966), where the arbitrator not only found that an agreement between employers and a civil rights group conflicted with a prior collective bargaining agreement but also purported to invalidate the civil rights agreement on the ground that it contravened state and national prohibitions of racial discrimination, even though the civil rights group was not a party to the arbitration.

34 See, e.g., Bethlehem Steel Co., 31 Lab. Arb. 423, 426 (1958).

35 Cf. Blumrosen, Public Policy Considerations in Labor Arbitration Cases, 14 RuTGers L. REv. 217, 222 (1960).

36363 U.S. at 597. 
of course, that the parties typically call on an arbitrator to construe and not to destroy their agreement. ${ }^{37}$ There is, moreover, no reason to credit arbitrators with any competence, let alone any special expertise, with respect to the law, as distinguished from the agreement. A good many arbitrators lack any legal training at all, ${ }^{38}$ and even lawyerarbitrators do not necessarily hold themselves out as knowledgeable about the broad range of statutory and administrative materials that may be relevant in labor arbitrations. Indeed, my impression-and it is only that-is that non-lawyer arbitrators are more willing to rush in where lawyers fear to tread. Here again an analogy to administrative tribunals is instructive. Such agencies consider themselves bound by the statutes entrusted to their administration and leave to the courts challenges to the constitutional validity of those statutes. Arbitrators should in general accord a similar respect to the agreement that is the source of their authority and should leave to the courts or other official tribunals the determination of whether the agreement contravenes a higher law. Otherwise, arbitrators would be deciding issues that go beyond not only the submission agreement but also arbitral competence. Arbitrators would, moreover, be doing so within a procedural framework different from that applicable to official tribunals. Finally, they would be impinging on an area in which courts or other official tribunals are granted plenary authority. ${ }^{39}$ Under such circumstances,

37 The parties may, of course, submit to an arbitrator either the issue of whether a given agreement is compatible with a pertinent statute or "problems" that result from the need to accommodate an agreement and the law. But such submissions, which may call for the reshaping of the agreement, are infrequent. In any event, there is not, in my opinion, any persuasive basis for giving any special deference to arbitral determinations as to the reach of the law. If, however, the parties have agreed to submit to the arbitrator issues as to the impact of regulation on the agreement and if his award is consistent with both the submission agreement and the law, there is no reason for the courts to withhold enforcement of the award.

38 It is true that NLRB members are not necessarily lawyers. But those who rely on that point to support an argument for broad arbitral jurisdiction over legal issues often ignore important differences between arbitrators and Board members: (1) The latter have a staff of legal advisors. (2) Board hearings are conducted by trial examiners who, under recent Civil Service requirements, must be duly licensed lawyers. U.S. Civil Service Comm., Announcement No. 318, Hearing Examiners 5 (1965). (3) Board members deal continuously with a single statute whereas arbitrators, if required to deal with the law governing collective agreements, would from time to time be confronted with a considerably broader range of national and unpreempted state regulation.

39 Although the Board's deference to arbitration is to be discussed by others, I wish in passing to express my strong doubts about its approach in the celebrated case of International Harvester Co., 138 N.L.R.B. 923, 51 L.R.R.M. 1155 (1962), affd, Ramsey v. NLRB, 327 F.2d 784 (7th Cir. 1964), cert. denied, 377 U.S. 1003 (1964); cf. Ford Motor Co., 131 N.L.R.B. 1462, 48 L.R.R.M. 1280 (1961). For a thoughtful criticism of International Harvester, see Summers, Labor Arbitration: A Private Process with a Public Function, 34 REV. JUR. U.P.R. 477, 492-94 (1965). 
the limited judicial review appropriate for arbitral interpretations of the agreement would be wholly inappropriate for arbitral interpretation of the law.

The position that I have outlined may be challenged on the following grounds, among others: It is wasteful and misleading for an arbitrator to render an award that is clearly repugnant to a controlling statute. Furthermore, insofar as such an award commands illegal conduct, it makes the arbitrator a party to illegality, requires a judicial proceeding to set things straight, ${ }^{40}$ and generally demeans the arbitration process by inviting non-compliance with, and reversal of, awards.

Although those considerations reflect a praiseworthy desire to have arbitrators solve the whole problem in a fashion compatible with the pertinent regulatory framework, they are, in my opinion, not persuasive. Any deception of the parties can be avoided by the arbitrator's noting that he is not passing on the validity of any contractual provision that appears to be questionable or invalid under the law. Similarly, if an award based solely on the agreement would call for illegal action, the arbitrator can make clear that his mandate is contingent on the legality of the contractual provision involved. In this connection, it should be observed that such provisional enforcement of illegal or unconstitutional provisions is a familiar and inescapable incident of the existence of multiple tribunals with different spheres of responsibility. ${ }^{41}$ Finally, a distinction between clear and not so clear statutory violations-which, incidentally, is Cutler-Hammer with a reverse twist -is likely to produce substantial administrative difficulties as well as bad law.

The overtime case I referred to previously is instructive on the last

40 It appears preferable to postpone judicial scrutiny of an arguably illegal contractual provision until an award has been rendered, thereby providing the opportunity for a construction of an ambiguous provision that would make it compatible with the law. It is true that such postponement might involve delays and industrial unrest, triggered by non-compliance with an arbitration award. But delay is an inescapable cost of any primary jurisdiction approach, and industrial unrest might be reduced by a clear statement by arbitrator and the parties concerning the existence of an unresolved issue of law.

Where an award is attacked in a judicial proceeding as contrary to the NLRA, judicial competence to deal with such questions may be challenged. For suggestions that such challenges should be rejected, see Meltzer, The Supreme Court, Congress and State Jurisdiction over Labor Relations II, 59 CoLUM. L. REv, 269, 291-92 (1959); Sovern, Section 301 and the Primary Jurisdiction of the NLRB, 76 HARv. L. REv. 529, 551, 564 (1963).

41. For example, an administrative agency may issue an order that it deems unconstitutional, leaving the constitutional issues to the courts. Similarly, it has been suggested that in actions covered by Section 301 of the LMRA, courts should enforce an agreement that is completely illegal in that, at the time of its execution, the union lacked majority support. See Meltzer, supra note 40, at 292-95, and Sovern, supra note 40, at 542-43. 
point. The arbitrator there relied on an Interpretative Bulletin issued under the FLSA and treated the interpretation as conclusive. ${ }^{42} \mathrm{He}$ made no reference to a well-known Supreme Court case which expressly denied conclusive effect to such interpretation. ${ }^{43}$ It is not clear from his award that the status of the interpretation bulletin was argued. In any event, that issue surely deserved more consideration than it appears to have been given.

Some persons may be ready to tax me with an inconsistency in that I am prepared to import something like the Cutler-Hammer test into judicial review of awards while rejecting a similar test as a basis for arbitral invalidation of a contractual provision clearly repugnant to an applicable statute. But the apparent inconsistency is not a real one because of the fundamental difference between the arbitral and judicial roles. An arbitrator is in general the proctor of the agreement and not of the statutes; thus, in the absence of arbitration he has no responsibility for the statutory scheme. Furthermore, he does not directly exercise the coercive power of the state. A court, by contrast, exercises such power and in doing so is concerned not only with the agreement but also with the law that limits and governs it. To grant courts limited responsibility for measuring the award against the agreement while denying arbitrators a similar responsibility for measuring the agreement against the law is, in each case, to confer responsibility that reflects the different functions being performed and the different presuppositions about the competence of the respective tribunals.

My discussion has, I know, not discharged my assignment, which called for an assessment of arbitration. As I have suggested, the heterogeneity and substantial invisibility of arbitration are serious obstacles to assessments that have a more substantial basis than the ideologies of hope or of despair. In addition, reliable assessments presuppose systematic study of the impact of the arbitration process on concrete relationships, on communications between managers and managed, on training, on morale in all echelons, on equity and efficiency, and on bargaining. To attempt to isolate arbitration from all other variables relevant to those matters is, I know, a tall order. Furthermore, in suggesting more research I have, unwisely perhaps, overcome my usual allergy to such suggestions that are not accompanied by detailed blueprints. I have done so because the National Academy of Arbitrators has made a useful beginning in stimulating such inquiries. They should, of course, be supplemented by additional and rigorously designed

42 See Pennsylvania Electric Co., 47 Lab. Arb. 526, 527-28 (1966).

43 See Skidmore v. Swift \& Co., 323 U.S. 134, 139 (1944); Idaho Metal Works v. Wirtz, 383 U.S. 190, 194, $207-08$ (1966); 1 Davis, AdMinistrative LAW TrEatisE, §§ 5.03-5.05 (1958). 
studies of how arbitrators are selected and by detached and systematic analysis of awards and the total adjudicative process. Since arbitrators may be reluctant to criticize each other and since the most qualified critics tend to be arbitrators, it would be desirable to stimulate such study by those courts of last resort for other forms of adjudication, namely, the law reviews. Perhaps the Academy might consider it desirable to stimulate such interest by offering prizes for excellent student work.

I do not mean to oversell the possible contribution of the studies I have mentioned to the resolution of the underlying controversies that surround arbitration. Similar studies of other adjudicative processes, such as my colleagues' study of the jury system, ${ }^{44}$ suggest that more data may narrow the issues but will not resolve the ideological conflicts that envelop all modes of adjudication. In the end, then, judgments about arbitration will rest on faith as well as reason. My own faith in the usefulness of arbitration and the integrity of arbitrators as a class has not been shaken by recent exercises in demonology. And the work of the Academy and the concern that it has reflected for the integrity and competence of arbitration will surely make it easier to keep the faith and, what is more important, will contribute to works appropriate to that faith.

44 See Kalven \& Zeised, The Ameriann Jury (1966). 